association basis. Although a body of theory for the design of such systems has been developed and tested successfully on a small scale, there are many practical technical problems to be solved before a useful system incorporating these concepts can be developed. Existing co-ordinate searching systems do not possess threo necessary characteristics: a capacity for generalizing a user's request to make it more compatible with the vocabulary of the retrieval system; a capacity to match automatically the usor's depth of search requirement to system parameters, by ranking the documents presented to users in decreasing order of probable relevance; a potential capacity of almost instantaneous reaction between user and searching machine, without need for a human intermediary.

\section{The Eastern European Academies of Sciences}

Publication 1090 of the National Academy of SciencesNational Research Council, The Eastern European Academies of Sciences : a Directory, represents a first attempt by the Office of the Foreign Secretary of the Academy to compile information on academies and research councils throughout the world (Pp. v+148. Washington, D.C.: National Academy of Sciences-National Research Council, 1963. 2 dollars). The academies of sciences described are those of Bulgaria, Czechoslovakia, Hungary, Poland, Rumania and Yugoslavia. The academies of sciences of the U.S.S.R. are not included since they have been the subject of other studies, the results of which are already available in the United States. The Directory presents a brief history of each academy, its presont organization, responsibilities, and the titles of its main periodicals. Rosters of leading academy officials and of affiliated institutes and their directors are also included, along with biographical sketches of prominent academicians in each country. It is claimed that tho survey reflects, as accurately as possible, the status of the academies and their principal personnel and programmes in December 1962. As a 'directory' the information supplied is not extensive, and does not supplant that available from, for example, The World of Learning, especially as the latter gives full lists of academicians and far more titles of poriodicals. Thus the use of the present publication will be as a reference guide to the policies and personalities of academies in eastern Europe.

\section{Perkin Centenary Awards}

Applications for the awards of the Perkin Centenary scholarships are invited by the Trustees. Each award, tenable for one or two years and renewable for a further year at the discretion of the Trustees, is offered to candidates employed in an industrial firm or other institution concerned with the manufacture or the application of colouring matters to study at a university or technical colloge. Two types of award are available, some to the value of $£ 100$, to be used in conjunction with a local education authority grant, and othors to the value of $£ 350$, which may bo increased to $£ 400$ for a student living away from home. Perkin Travel Grants are also available. Howover, the Perkin Centenary Fellowship will not be awarded in the year 1964-65. Further information can be obtained from the Socretary, Perkin Centenary Trust, e/o the Chemical Society, Burlington House, London, W.1.

\section{Does Instrumentation Pay?}

Following the success of its symposium last year, when more than 100 applicants had to be turned down because of lack of space, the South Yorkshire section of the Society of Instrument Technology is organizing another one-day event in Shoffield on October 24. The theme of this year's symposium is "Instrumentation and ControlDoes it Pay?" Intended as the South Yorkshire section's contribution to National Productivity Year, the Memorial Hall of Sheffield City Hall has been booked in anticipation of a large attendance. Nine speakers will talk on various aspects of instrumentation and control, drawing extensively from their own practical experience. Special emphasis will be directed towards the needs of the smaller firm, where lack of knowledge tends to restrict the opportunitios for the application of rolatively inexpensive control systems. Speakers will include R. Barber (Land Pyrometers Ltd., and chairman of the South Yorkshire Section of the Society of Instrument Technology); M. A. Thomas (Steel, Peech and Tozor); B. O. Smith (Honeywell Controls Ltd.); Dr. P. Bacon (Guest Keen Iron and Steel Co. Ltd.); H. B. Western (National Industrial Fuel Efficiency Service); J. Hancock (Unbrako Steel Co. Ltd.); A. Barker and R. F. Wright (Thos. Firth and John Brown Ltd.); I. C. Ross (Steel, Peech and Tozer). The symposium will conclude with an open forum under the chairmanship of Mr. Barber. Further information can be obtained from C. G. Hague, A.C.E.-Hartons Ltd., 109, Rockingham Lane, Sheffield, 1. An attendance fee of one guinea is being charged for the meeting.

\section{Announcements}

THE twenty-first annual Pittsburgh Diffraction Conference will bo held at the Mellon Institute, Pittsburgh, Pennsylvania, during November 6-8. Further information can be obtained from W. M. Biagas, Crucible Steel Company, P.O. Box No. 7257, Pittsburgh 13, Pennsylvania.

A symposium on "The Toxicology of Cosmetic Materials" will be held at the Town Hall, Leamington Spa, during November 19-20, by the Society of Cosmetic Chemists of Great Britain. Registration forms together with full details can be obtained from the general secretary, Mrs. E. Millman, 2 Lovers Walk, London, N.3.

THREE short coursos are being organized by Bradford Institute of Technology during November on "Developments in Polymerization" (November 8-9), "Recent Industrial Applications of X-ray and Electron Diffraction" (November 14-15), and "New Techniquos in the Study of Materials" (November 22-23). Further information and application forms can bo obtained from the Registrar, Bradford Institute of Technology, Bradford 7.

A series of courses of special lectures in higher technology will be held at Woolwich Polytechnic during the academic year 1963-64. These will include courses in: mathernatics; physics and telecommunications; chemistry; biology; civil, mochanical and production engineering; electrical ongineering; economics and management. Further information can bo obtained from the Secretary, Woolwich Polytechnic, Woolwich, London, S.E.18.

THE ninth annual conference on "Magnetism and Magnetic Materials", sponsored by the American Institute of Physics and the Institute of Electrical and Eloctronics Engineers, will be hold in Atlantic City during November 12-15. In addition to the usual topics the Committee is encouraging papers relating to superconductivity and magnetism. Further information can be obtained from Mr. William D. Doyle, Franklin Institute Laboratories, Philadelphia 3, Pennsylvania.

Erratum. There is an omission of two OH groups from the formula of orgoflavin given in the summary of Prof. J. Monteath Robertson's prosidential address to Section $B$ (Chemistry) at the Aberdeen meeting of the British Association for the Advancement of Science, which appears on p. 883 of the August 31 issue of Nature. The formula should be:

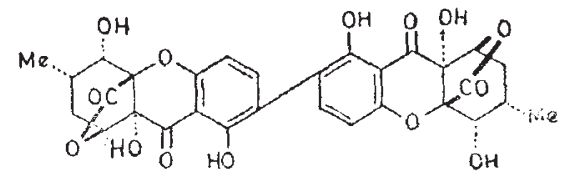

